\title{
Improving of fatty acids profile of fillets shehri (Lethrinus microdon) during freezing by packaging under vacuum system
}

\section{Aprimoramento do perfil de ácidos graxos de filés de shehri (Lethrinus microdon) durante o congelamento por embalagem sob sistema a vácuo}

\author{
1, (iD Soad VOSTAIEA, ${ }^{2, *(D)}$ Ali ABEROUMAND and 3, (iD Laleh ROOMIANI \\ 1 Department of Food Science and Technology, Ahvaz Branch, Islamic Azad University, Ahvaz, Iran. Email address: \\ yasna.vs2027@gmail.com.I.roomiani@yahoo.com
}

2 Department of Fisheries, Natural Resources Faculty, Behbahan Khatam Alanbia University of Technology, Behbahan, Iran, Phone: +98-9167277178, Fax: +98-67152729969. Postal Addresses: No: 22, second Alley of Ab va barg, Zolfegari, Behbahan, Khuzestan, Iran. P.O. Box 63616-13517.

3 Department of Fisheries, Ahvaz Branch, Islamic Azad University, Ahvaz, Iran

*Corresponding author: aberoumandali@yahoo.com

\section{OPPEN ACESS}

\section{Additional information}

Received: 10/25/2016

Accept: 02/14/2017

Published: 08/08/2017

Editor:

Irene Rodrigues Freitas Universidade do Oeste Paulista, Presidente Prudente, SP.

irfreitas@yahoo.com.br

\section{Double blind reviews}

Reviews process

Prot. $1252016 R 01$ (Brazil)

Prot. $1252017 R 03$ (Brazil)

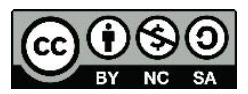

JBFS all rights

Copyright: @ 2017

\section{ABSTRACT}

Aim of this research was to study on effect of vacuum packaging on fatty acids profiles changes in Lethrinus microdon fish fillet during frozen storage up to 40 days. Palmitic acid (C16:0) and stearic acid (C18:0) were the major fatty acids among the SFAs (Saturated Fatty Acids) during storage. Also lowest values of $0.263 \%$ of cis-10pentadecenoic acid (C15:1) were found in control samples and vacuum packaging, respectively. A decrease was observed in MUFA (Monounsaturated Fatty Acids) value with increased storage period in treatments $(p<0.05)$. Oleic acid content (C18:1 n-9) in control (23.64\%) and vacuum packaged samples $(26.07 \%)$ was higher than that of other fatty acids. All samples showed a decreased PUFA value with increased storage $(p<0.05)$. It can be concluded that packaging samples under vacuum and freezing conditions was a suitable way to reduce Shehri (Lethrinus microdon) fillet unsaturated fatty acids oxidation and to avoid them reduction, cause to extend their shelf life.

Keywords: Fatty acids profile. Vacuum packaging. Freezing.

\section{RESUMO}

O objetivo desta pesquisa foi estudar o efeito da embalagem a vácuo nas alterações dos perfis de ácidos graxos no filé de peixe Lethrinus microdon durante o armazenamento sob congelamento até 40 dias. 0 ácido palmítico (C16:0) e o ácido esteárico (C18:0) foram os principais ácidos graxos entre os ácidos saturados durante o armazenamento. Também foram encontrados valores mais baixos 0,263\% de ácido cis-10-pentadecenoico (C15: 1) em amostras de controle e em embalagens a vácuo, respectivamente. Observou-se uma diminuição no valor dos ácidos monoinsaturados com aumento do período de armazenamento nos tratamentos $(p<0,05)$. 0 teor de ácido oleico (C18: 1 n-9) no controle $(23,64 \%)$ e amostras embaladas a vácuo $(26,07 \%)$ foi maior que o de outros ácidos gordos. Todas as amostras mostraram um valor de ácidos graxos poliinsaturados diminuído com o maior armazenamento $(p<0,05)$. Pode-se concluir que as amostras de embalagens sob condições de vácuo e congelamento eram uma maneira adequada de reduzir a oxidação de ácidos graxos insaturados de filé de Shehri (Lathrinus microdon) e evitar a redução, causando a extensão da sua vida útil.

Palavras-chave: Perfil de ácidos graxos. Embalagem à vácuo. Congelmaneto. 


\section{INTRODUCTION}

Lethrinus fish is an important genus belonging to the Lethrinidae family. It includes 27 species. Species are found in the Persian Gulf Region, mainly in MiddleEastern countries. Lethrinus microdon is a widespread species. It has been recorded in the Red Sea, Persian Gulf, Arabian Sea, from East Africa to Sri Lanka. Lethrinus microdon feeds in the day and at night, and is known to feed mainly on other fishes, cephalopods, crustaceans, and polychaetes. This species is fished commercially and is considered to be an excellent food fish. It is usually marketed fresh and not frozen (CARPENTER; ALLEN, 1989). With regard to increasing growth of population in world especially in developing countries and providing nutrients for people, aquaculture is considered as one of the most important sectors in ensuring the food needed for people. That is why aquaculture is in progress in Iran and therefore different methods of maintenance and distribution such as frozen packing of aquatic products is increasing in Iran. Fish freshness is fundamental and essential to fish quality. Freezing and frozen storage of fish have been largely used to retain fish nutritional values and properties (MADRID; MADRID; MADRID, 1994; ERICKSON, 1997).

Changes in lipid occur through hydrolysis and oxidation reactions. According to Haard (2002) fish lipids are subjected to two main changes, lipolysis and autooxidation. The main reactants in these processes involves atmospheric oxygen and fish unsaturated lipids, leading to the formation of hydroperoxides, associated with tasteless, flavor and accompanied by brown yellow discoloration of the different fish species tissue (HUSS, 1993). Upon further degradation of hydroperoxides is the formation of strong rancid flavors e.g. aldehydes and ketones, usually associated with spoilage fatty and inedible of fish species (ASHTON, 2002).

Fish are considered as an important part of human nutrition, because of their high contents in polyunsaturated fatty acids (PUFAs), especially of the $n-3$ and n-6 series. These unsaturated fatty acids are highly susceptible to oxidation reactions (PETTERSEN et al., 2004). Lipid oxidation reactions is one of the major problems in the fish industry and post processing, due to the resultant flavor deterioration and loss of nutritional value (MEDINA; GALLARDO; AUBOURG, 2009). In order to minimize such undesirable effects, different technological ways have been applied such as low temperature storage, preserving packaging and the incorporation of antioxidants (MEDINA; GALLARDO; AUBOURG, 2009; TAHERI, 2012). One of the suitable methods to access this target is using vacuum packaging in order to control rancidity and oxidation in fish oil (ROSTAMZAD et al., 2010). Vacuum packaging is a way for delaying lipid oxidation reactions because of limiting oxygen molecules. As reported by Anelich, Hoffman and Swanpoel (2001), Fagan and Gormley (2004) and PerezAlonso et al. (2004), packaging under vacuum has positive effect on extended shelf life of fish fillets and acceptability.

Vacuum packaging is an application method through with the air is emptied out of the bag and then it is packed completely (ARASHISAR, 2004). There are different methods to maintain the food which are mainly used to remove microorganisms and inactivation of enzymes. Vacuum packing is a method to delay the spoilage of fish products which keeps the fish non-perishable for a longer time and maintains the overall quality of fish muscle. Vacuum packaging may be defined as the packaging of a product in a high barrier package from which air and moisture is removed to prevent growth of aerobic spoilage organisms, shrinkage, oxidation and color and texture deterioration (GONÇALVES; RIBEIRO, 2008). Some research has claimed that storing fish under vacuum delays bacterial growth and increases the shelf life and healthy 
(SAWANT et al., 2012). Aim of this research was to study on the effect of vacuum packaging on changes of fatty acids profile of Shehri fish fillet during frozen storage up to 40 days.

\section{MATERIAL AND METHODS}

\section{Sample preparation}

Fresh Shehri (Lethrinus microdon) were caught ( $4.8 \mathrm{~kg}$ ) in the Persian Gulf near Bandar Abadan (Khuzestan Province, South Iran). The average length and weight were $43 \pm 1.4 \mathrm{~cm}$ and $1.41 \pm 1.2 \mathrm{~kg}$, respectively. The fish were placed in boxes with ice and transferred for analysis to Central laboratory of analysis of biological and chemical of aquatic feed, Sari city, Mazandaran province (Scientific Research Center), Iran. Fish samples were beheaded, gutted and filleted by hand and washed with cold water $\left( \pm 2{ }^{\circ} \mathrm{C}\right)$ and a chloroform/methanol mixture $(2: 1, \mathrm{v} / \mathrm{v})$ containing $0.01 \%$ butylated hydroxytoluene (BHT). The fillets were then divided into 3 groups. The samples were divided into three groups of two members. The first group was to name of fresh fillets in individual polyamide/polyethylene bags at zero time, under vacuum. The second group to name of fresh fillets in individual polyamide/polyethylene bags with frozen 20 days under vacuum. The third group to name of fresh fillets in individual polyamide/polyethylene bags with frozen 40 days under vacuum. All packaged samples were very fast frozen at -26 으. After 36 hours, all fish fillets were placed in a $(-18$ o $C)$ freezer. Analyses of the fish fillet in both groups were carried out after the freezing process ( 0 -day storage at $-18^{\circ} \mathrm{C}$ ), and after 20 and 40 days of storage at (18 ㄷ). In all cases, thawing was carried out by refrigerated storage (4ㄷ) over night. For each kind of fillet, three different batches $(n=3)$ were considered and analyzed separately in order to achieve the statistical analysis.

\section{Fatty acid analysis}

Total lipids were extracted by a chloroform-methanol mixture, according to the Bligh and Dyer (1959) method. Lipid extracts were then saponified with $0.5 \mathrm{~N}$ methanolic $\mathrm{NaOH}$ and further trances terified with $\mathrm{BF}_{3}$ (Boron trifluoride) in methanol (AOAC, 2005). The resulting fatty acid methyl esters (FAME) were analyzed on a Gas Chromatograph (DANI 1000) equipped with a Flame Ionization Detector (FID). The fatty acid esters were separated on a SGE column ( $30 \mathrm{~m} 30.25 \mathrm{~mm}$ i.d., $0.2 \mu \mathrm{m}$ film thickness) using helium as the carrier gas at a flow rate of $1.2 \mathrm{~mL} \mathrm{~min}^{-1}$. The temperature and other chromatographic conditions employed were as follows: initial temperature $(175 \circ \mathrm{C})$, heating rate $\left(1 \stackrel{\circ}{ } \mathrm{min}^{-1}\right)$, final temperature $(220 \circ \mathrm{C})$, end time (20 min), injector temperature $\left(250^{\circ} \mathrm{C}\right)$ and detector temperature $(270 \circ \mathrm{C})$. FAME were identified by comparison of the retention times with those of standard (C19:0, Sigma) purified fatty acids (LIU et al., 2009). Peak areas were electronically integrated and quantified; results are expressed as percentage of total FAME. The polyene index $(\mathrm{PI})$ was calculated as the following fatty acid concentration ratio: [20:5n-3+22:6n-3)/16:0]

Each sample was repeated three times and its average was calculated. 


\section{Statistical Analysis}

The mean and standard deviation were calculated for all data. Results were subjected to one-way analysis of variance followed by Duncan's entire comparison test, using a software SPSS 16.0. For all statistical to determine significant differences among treatment means. All data are presented as the mean \pm SD.

\section{RESULTS AND DISCUSSION}

Fatty acids composition

Different fatty acids were identified and quantified in Shehri fillet samples the results obtained throughout a 40 days frozen storage period corresponding to treated and untreated fish are shown in Tables (1 and 2).

Table 1. Changes in fatty acids composition of fresh (control) Shehri fillets during frozen storage up to 40 days in $-18 \circ \mathrm{C}$.

\begin{tabular}{crrr}
\hline & \multicolumn{3}{c}{ Time of storage (days) } \\
\cline { 2 - 4 } Fatty acids & \multicolumn{1}{c}{0} & \multicolumn{1}{c}{20} & \multicolumn{1}{c}{40} \\
\hline C14:0 & $2.873 \pm 0.04 \mathrm{a}$ & $2.303 \pm 0.06 \mathrm{~b}$ & $2.619 \pm 0.08 \mathrm{c}$ \\
C15:0 & $1.609 \pm 0.12 \mathrm{a}$ & $1.224 \pm 0.18 \mathrm{~b}$ & $1.370 \pm 0.5 \mathrm{~b}$ \\
C16:0 & $27.686 \pm 0.03 \mathrm{a}$ & $18.723 \pm 0.05 \mathrm{~b}$ & $22.795 \pm 0.09 \mathrm{c}$ \\
C17:0 & $1.799 \pm 0.15 \mathrm{a}$ & $1.929 \pm 0.09 \mathrm{~b}$ & $1.790 \pm 0.02 \mathrm{a}$ \\
C18:0 & $9.858 \pm 0.16 \mathrm{a}$ & $10.467 \pm 0.09 \mathrm{~b}$ & $11.496 \pm 0.08 \mathrm{c}$ \\
C20:0 & $0.343 \pm 0.08 \mathrm{a}$ & $0.781 \pm 0.05 \mathrm{~b}$ & $0.532 \pm 0.06 \mathrm{c}$ \\
C24:0 & $1.185 \pm 0.04 \mathrm{a}$ & $2.791 \pm 0.09 \mathrm{~b}$ & $1.729 \pm 0.05 \mathrm{c}$ \\
\hline SSFAs & $45.353 \pm 0.62 \mathrm{a}$ & $38.218 \pm 0.61 \mathrm{~b}$ & $42.331 \pm 0.88 \mathrm{c}$ \\
\hline C14:1 & $0.300 \pm 0.09 \mathrm{a}$ & $0.429 \pm 0.07 \mathrm{~b}$ & $\mathrm{~N} . \mathrm{D}$. \\
C15:1 & $0.263 \pm 0.01 \mathrm{a}$ & $0.304 \pm 0.05 \mathrm{~b}$ & $\mathrm{~N} . \mathrm{D}$. \\
C16:1 & $6.213 \pm 0.01 \mathrm{a}$ & $5.989 \pm 0.08 \mathrm{~b}$ & $5.595 \pm 0.07 \mathrm{c}$ \\
C17:1 & $1.180 \pm 0.04 \mathrm{a}$ & $0.712 \pm 0.13 \mathrm{~b}$ & $1.347 \pm 0.17 \mathrm{c}$ \\
C18:1n9 cis & $23.646 \pm 0.02 \mathrm{a}$ & $19.455 \pm 0.07 \mathrm{~b}$ & $20.652 \pm 0.06 \mathrm{c}$ \\
C20:1n9 & $2.069 \pm 0.12 \mathrm{a}$ & $2.623 \pm 0.18 \mathrm{~b}$ & $0.841 \pm 0.08 \mathrm{c}$ \\
C24:1n9 & $0.928 \pm 0.08 \mathrm{a}$ & $0.210 \pm 0.05 \mathrm{~b}$ & $1.656 \pm 0.06 \mathrm{c}$ \\
\hline LMUFAs & $34.599 \pm 0.38 \mathrm{a}$ & $29.722 \pm 0.83 \mathrm{~b}$ & $30.091 \pm .44 \mathrm{c}$ \\
\hline C18:2n6 cis & $1.039 \pm 0.06 \mathrm{a}$ & $2.113 \pm 0.07 \mathrm{~b}$ & $4.449 \pm 0.04 \mathrm{c}$ \\
C22:2 & $3.442 \pm 0.08 \mathrm{a}$ & $4.112 \pm 0.03 \mathrm{~b}$ & $2.863 \pm 0.07 \mathrm{c}$ \\
C20:3n3 & $3.516 \pm 0.07 \mathrm{a}$ & $5.114 \pm 0.05 \mathrm{~b}$ & $4.183 \pm 0.04 \mathrm{c}$ \\
C22: $5 n-3(\mathrm{DPA})$ & $1.207 \pm 0.09 \mathrm{a}$ & $2.627 \pm 0.18 \mathrm{~b}$ & $1.564 \pm 0.7 \mathrm{c}$ \\
C22: $6 n-3(\mathrm{DHA})$ & $6.835 \pm 0.03 \mathrm{a}$ & $8.197 \pm 0.05 \mathrm{~b}$ & $7.623 \pm 0.09 \mathrm{c}$ \\
\hline CPUFAs & $16.039 \pm 0.33 \mathrm{a}$ & $22.163 \pm 0.38 \mathrm{~b}$ & $20.682 \pm 0.94 \mathrm{c}$ \\
\hline
\end{tabular}

SFAs - Saturated Fatty Acids; MUFAs - Monounsaturated Fatty Acids; PUFAs - Polyunsaturated Fatty Acids. Means in a row with different letters indicate significant differences $(p<0.05)$ as result of frozen storage time. ND: Non-detected. Means $\pm S D(n=3)$. 
Table 2. Changes in fatty acids compositions of vacuum treated Shehri fillets during frozen storage up to 40 days in $-18^{\circ} \mathrm{C}$.

\begin{tabular}{|c|c|c|c|}
\hline \multirow{2}{*}{ Fatty acids } & \multicolumn{3}{|c|}{ Time of storage (days) } \\
\hline & 0 & 20 & 40 \\
\hline $\mathrm{C} 14: 0$ & $2.876 \pm 0.02 a$ & $2.629 \pm 0.07 b$ & $2.183 \pm 0.04 c$ \\
\hline C15:0 & $1.609 \pm 0.04 a$ & $1.496 \pm 0.05 b$ & $0.790 \pm 0.09 b$ \\
\hline $\mathrm{C} 16: 0$ & $27.686 \pm 0.03 a$ & $21.286 \pm 0.04 b$ & $31.077 \pm 0.08 c$ \\
\hline $\mathrm{C} 17: 0$ & $1.799 \pm 0.04 a$ & $1.840 \pm 0.08 \mathrm{~b}$ & $0.771 \pm 0.03 a$ \\
\hline C18:0 & $9.858 \pm 0.02 a$ & $9.491 \pm 0.04 b$ & $5.871 \pm 0.01 \mathrm{c}$ \\
\hline C20:0 & $0.371 \pm 0.12 a$ & $0.622 \pm 0.08 \mathrm{~b}$ & $1.278 \pm 0.04 c$ \\
\hline $\mathrm{C} 24: 0$ & $1.195 \pm 0.08 a$ & $2.652 \pm 0.12 b$ & $0.423 \pm 0.15 c$ \\
\hline$\sum$ SFAs & $45.394 \pm 0.35 a$ & $40.016 \pm 0.48 b$ & $42.393 \pm 0.44 c$ \\
\hline $\mathrm{C} 14: 1$ & $0.303 \pm 0.05 a$ & $0.560 \pm 0.09 b$ & N.D \\
\hline C15:1 & $0.263 \pm 0.04 a$ & $0.341 \pm 0.09 b$ & N.D \\
\hline C16:1 & $6.213 \pm 0.02 a$ & $6.678 \pm 0.09 b$ & $3.159 \pm 0.03 c$ \\
\hline $\mathrm{C} 17: 1$ & $1.180 \pm 0.05 a$ & $0.639 \pm 0.09 b$ & $0.569 \pm 0.03 c$ \\
\hline C18:1n9 cis & $23.646 \pm 0.08 a$ & $19.984 \pm 0.13 b$ & $26.074 \pm 0.16 c$ \\
\hline C20:1n9 & $2.069 \pm 0.03 a$ & $2.017 \pm 0.07 \mathrm{~b}$ & N.D \\
\hline C24:1n9 & $0.928 \pm 0.03 a$ & $2.316 \pm 0.11 b$ & $0.696 \pm 0.16 c$ \\
\hline$\sum$ MUFAs & $34.592 \pm 0.33 a$ & $32.535 \pm 0.67 b$ & $30.498 \pm 0.38 c$ \\
\hline $\mathrm{C} 18: 2 \mathrm{n} 6 \mathrm{cis}$ & $1.039 \pm 0.06 a$ & $1.445 \pm 0.15 b$ & $1.562 \pm 0.15 c$ \\
\hline $\mathrm{C} 22: 2$ & $3.435 \pm 0.04 a$ & $3.605 \pm 0.07 b$ & $0.305 \pm 0.03$ \\
\hline$C 20: 3 n 3$ & $3.518 \pm 0.08 a$ & $6.036 \pm 0.05 b$ & $1.994 \pm 0.03 c$ \\
\hline C22: 5n-3(DPA) & $1.232 \pm 0.03 a$ & $2.246 \pm 0.07 \mathrm{~b}$ & $0.336 \pm 0.04 c$ \\
\hline C22: 6n-3(DHA) & $6.842 \pm 0.08 a$ & $9.934 \pm 0.03 b$ & $2.460 \pm 0.02 c$ \\
\hline$\sum$ PUFAs & $16.066 \pm 0.29 a$ & $23.266 \pm 0.37 b$ & $6.657 \pm 0.27 c$ \\
\hline
\end{tabular}

SFAs - Saturated Fatty Acids; MUFAs - Monounsaturated Fatty Acids; PUFAs - Polyunsaturated Fatty Acids. Means in a row with different letters indicate significant differences $(p<0.05)$ as result of frozen storage time. ND: Non-detected. Means \pm SD $(n=3)$.

The changes in fatty acids composition during storage in frozen conditions were statistically significant $(p<0.05)$. Except for zero time, significant differences were observed among the saturated fatty acids during frozen storage in control samples $(p<0.05)$ but significantly differences were detected in samples treated with vacuum packing after 20 and 40 days storage $(p>0.05)$. All samples showed an increased SFA value with increased storage $(p<0.05)$. Palmitic acid $(C 16: 0)$ and stearic acid (C18:0) were the major fatty acids among the SFAs during storage. Also minimum values of $0.263 \%$ and $0.263 \%$ of cis-10-pentadecenoic acid (C15:1) were found in control samples and vacuum packaging, respectively (Tables 1,2$)$. There were significant differences among polyunsaturated fatty acids (PUFA) contents during 40 days $(p<0.05)$. All samples showed a decreased PUFA value with increased storage except vacuum packaging with 20 days frozen storage $(p<0.05)$ that fatty acid value of $C 22$ : $6 \mathrm{n} 3$ was high. There were significantly differences among MUFA (monounsaturated fatty acids) contents during 40 days storage $(p<0.05)$. A decrease was observed in 
MUFA value with increased storage period in both treatments $(p<0.05)$. Oleic acid content (C18:1 n-9) in control (\%23.64) and vacuum packaged samples $(26.07 \%)$ was higher than that of other fatty acids (Tables 1,2). All samples showed a decreased PUFA value with increased storage $(p<0.05)$. It is observed that both linoleic $(C 18: 2 n-6)$ and docosahexaenoic acid [DHA (22:6n-3)] were predominant in the total $n-6$ polyunsaturated fatty acids in fillets of Shehri fish fillets in all treatments. Among omega-3 fatty acids, docosahexaenoic acid (C22:6n-3) was identified in our study and was high. Distribution of fatty acids in control and treatments samples were in the order of SFA > MUFA > PUFA, but unsaturated fatty acids were more than saturated fatty acids (SFA<PUFA+MUFA) in treatments. An increase was observed in the percentage of SFA in control and vacuum packing from $45.31 \%$ to $54.72 \%$ and $81.99 \%$ to $42.30 \%$, respectively. A significant reduction was observed in the percentage of MUFA from $33.58 \%$ to $25.07 \%, 34.57 \%$ to $30.47 \%$ in control, respectively after 40 days storage under frozen conditions $(\mathrm{p}<0.05)$. Also a significant increase was observed in the percentage of PUFA from $12.57 \%$ to $17.80 \%, 2.61 \%$ to $24.34 \%$ in vacuum packing, respectively after 40 days storage under frozen conditions $(p<0.05)$.

The fatty acid profiles were identified for 12 samples by GC. The most abundant fatty acids composition of fresh (control) fillets during frozen storage at 0 day found C16:0 (palmitic acid) and C18:1n-9 (oleic acid), followed by C18:0 (stearic acid),C22:6n3 and C16:1 respectively. The most abundant fatty acids composition of fresh (control) fillets during frozen storage at 20 days found C18:1n-9 and C16:0, followed by $\mathrm{C} 18: 0, \mathrm{C} 22: 6 \mathrm{n} 3$ and $\mathrm{C} 20: 3 \mathrm{n} 3$ respectively. The most abundant fatty acids composition of fresh (control) fillets during frozen storage at 40 days found $\mathrm{C} 16: 0$ and $\mathrm{C} 18: 1 \mathrm{n}-9$, followed by $\mathrm{C} 18: 0, \mathrm{C} 22: 6 \mathrm{n} 3$ and $\mathrm{C} 16: 1$. The most abundant fatty acids composition of vacuum treated fish fillets during frozen storage at 0 day found C16:0 (palmitic acid) and C18:1n-9 (oleic acid), followed by C18:0 (stearic acid), C22:6n3 and $\mathrm{C} 16: 1$. The most abundant fatty acids composition of vacuum treated fish fillets during frozen storage at 20 days found $C 18: 1 n-9$ and $C 22: 6 n 3$, followed by $C 16: 0$ and $C 16: 1$. The most abundant fatty acids composition of vacuum treated fish fillets during frozen storage at 40 days found $\mathrm{C} 16: 0$ (palmitic acid) and C18:1n-9 (oleic acid), followed by C18:2n6, C18:0 and C16:1. With regards to PUFA, C22:6n-3 (docosahexaenoic acid) and C18:2n-6 (linoleic acid) were found to be the most abundant. The present results agree with those obtained by Liu et al. (2009). In this research, different tissue locations were analyzed all of which showed C18:1n-9 and C16:0 as the most abundant fatty acids; among PUFA, C22:6n-3 were predominant. Also Khristoferzen (1969) found a higher PUFA content in wild fish from the Indian Ocean when compared to the current study.

Previous research related to the frozen storage of fish species has already shown that unsaturated lipids are likely to be oxidized. Thus, Serdaroglu and Felekoglu (2005) reported that SFA and PUFA contents increased and decreased, respectively, in minced sardine (Sardina pilchadus) muscle when stored at $-20^{\circ} \mathrm{C}$ for up to 5 months. A similar behavior was found for both fatty acids groups present in frozen $(-30 \circ \mathrm{C})$ Spanish mackerel (Scomberomorus commersoni) and white cheek shark (Carcharhinus dussumieri) fillets (NAZEMROAYA et al., 2009). The decrease in the PUFA concentrations is commonly is related to oxidation reactions and it is normally accepted that the oxidation rate increases with the degree of unsaturation (SALDANHA; BRAGAGNOLO, 2008).

The total $\omega-6$ fatty acids in control samples and vacuum treatment were found to be higher than of $\omega-3$ fatty acids in fillets of Shehri fish (Tables 1 and 2). Significantly lower level of $\omega-3$ and $\omega-6$ fatty acids were found in control samples $(p<0.05)$. The $\omega-3$ PUFA was in control samples and vacuum packaging of the total fatty acids, most 
abundant of which was DHA (C22:6n-3) in all treatments (Tables 1 and2). The $\omega-6$ PUFA were present in control samples and vacuum packaging of the total fatty acids and were mainly linoleic acid (C18:2n-6). Marine fish are rich in $\omega-3$ fatty acids, especially DHA and EPA (CELIC; DILER; KUCUKGULMEZ, 2005). It has been reported that the types and amounts of fatty acids in fish fillet vary with the geographic location, size, genetic, age, what the fish eat, reproductive status and season (CELIC; DILER; KUCUKGULMEZ, 2005).

It is known that $\omega-3$ and $\omega-6$ fatty acids have an essential role in the human diet to prevent diseases and to ensure the healthy. Since these compounds are typical of seafood and Shehri fillets contain higher amounts of these fatty acids, the losses observed in the DPA and DHA contents are especially important. The losses of these products were probably related to autoxidation reactions of the lipids. These results are in agreement with other research Saldanha and Bragagnolo (2008),.Celic, Diler and Kucukgulmez (2005), Selami and Sadoki (2008), which reported a decrease in the $\omega-3$ and $\omega-6$ fatty acids levels during frozen storage in fish samples. The results obtained which are related to the effect of vacuum packaging on the fatty acids composition of Shehri fillets throughout the frozen storage 40 days period can be seen in Table 2 . Finally, the treated fish showed a higher $\omega-6 / \omega-3$ ratio when compared to the untreated fish. Totally, the results showed that usage of vacuum packaging found a positive influence on delaying lipid oxidation and increasing shelf-life of fillets $(p<0.05)$.

Industry requirements always requires valuable and practical actions that may lead to an increase in commercial facilities. A vacuum packaging with like easy availability and low commercial cost can be considered as most suitable. The commercial frozen storage with a low-oxygen permeability packaging and suitable time during and conditions was more effective in preventing lipid oxidation than highoxygen permeability packaging (SALDANHA; BRAGAGNOLO, 2008). The present research agreed with previous research where a packing treatment in a vacuum system was found useful in order to increase the quality retention and shelf life of frozen fish. Thus, vacuum packaging has been successfully employed in different kinds of fish species such as sardines (S. pilchardus) Ozogol, Polat and Ozogul (2004) and Persian sturgeon (Acipenser persicus) (ROSTAMZAD et al., 2010).

\section{CONCLUSIONS}

According to the present results, packaging samples under vacuum and freezing conditions was a suitable way to reduce unsaturated fatty acids oxidation of Shehri (Lethrinus microdon) fillets and to avoid reducing them, cause to extend their shelf life and healthy by limiting available oxygen.

\section{ACKNOWLOGDES}

This research project was funded by Ahvaz Branch, Islamic Azad University, Iran, all authors wish to thank to Behbahan Khatam Alanbia University of Technology, and Ahvaz Branch, Islamic Azad University for provide facilities.

\section{AUTHOR CONTRIBUITION}

The Dr. Ali Aberoumand, PhD in Food Science, accompanied the studies on freezing fillet fish Lethrinus microdon under vacuum system for Improving of fatty acids profile, and participated in the sequence alignment and drafted the manuscript. The researchers from Department of Fisheries, Ahvaz Branch, Islamic Azad University, Ahvaz, Iran, Dr. Laleh Roomiani and MSc student Soad Vostaiea and Dr. Ali Aberoumand from 
Behbahan Khatam Alanbia University of Technology, Behbahan, Iran,, for using this laboratory, and supporting of samples analysis, as well contributed to the suggestion of scientific references. The author, Dr. Ali Aberoumand for carrying out the manuscript. Dr. Laleh Roomiani as project advisor and reviewer activities.

\section{CONFLICT OF INTEREST}

The authors declare that there are no conflict of interest.

\section{FUNDING}

The authors received funding this work the Department of Food Science and Technology, Ahvaz Branch, Islamic Azad University, Ahvaz, Iran.

\section{REFERENCES}

Alonso I, and Borderias A, (2008). Technological effect of red grape antioxidant dietary fiber added to minced fish muscle. Journal of Food Science and Technology 43: 1009-1018.

Anelich L.E, Hoffman L.C and Swanpoel M.J. (2001). The influence of packaging methodology on the microbiological and fatty acid profiles of refrigerated African catfish fillets. Journal of Applied Microbiology: 91: 22-28. DOI: 10.1046/j.1365-2672.2001.01346.x.

AOAC. (2005). Official methods of analysis. 17thEd. Association of Official Analytical Chemists, Washington, Arlington, USA.

Arashisar S.U, Hisar O, Kaya M., and Yanik T. (2004). Effects of modified atmosphere and vacuum packaging on microbiological and chemical properties of rainbow trout (Oncorhynchus mykiss) fillets. International Journal of Food Microbiology 97: 209-214. DOI:10.1016/j.ijfoodmicro.2004.05.024.

Ashton, I.P (2002). Understanding lipid oxidation in fish. In: Bremner H A, editor. Safety and quality issues in fish processing. Wood head Publishing Ltd. Cambridge. 254-285.

Bligh E, and Dyer W. (1959). A rapid method of total extraction and purification. Canadian Journal of Physiology and Pharmacology 37: 911-917. DOI:10.1139/059-099.

Carpenter K.E, and Allen G.R. (1989), FAO species catalogue. Emperor fishes and large-eye breams of the world (family Lethrinidae). An annotated and illustrated catalogue of lethrinid species known to date. FAO Fish. Synop. 125(9): Rome: FAO .Vol. 9. 118.

Celic M, Diler A, and Kucukgulmez A. (2005). A comparison of the proximate compositions and fatty acid profiles of Zander (Sander lucioperca) from two different region and climatic condition. Journal of Food Chemistry 92: 637641. DOI: 10.1016/j.foodchem.2004.08.026.

Erickson M. (1997). Lipid oxidation: Flavor and nutritional quality deterioration in frozen foods. In: Erickson M, Hung Y C, Editors. Quality in frozen food. Chapman and Hall: New York (USA); 141-173.

Fagan JD, and Gormley TR. (2004). Effect of modified atmosphere packaging with freeze-chilling on some quality parameters of raw white, mackerel and salmon portions. Innovation Food Science and Emerging Technology 5: 205-214. DOI:10.1016/j.ifset.2004.01.001.

Gonçalves A.A, and Ribeiro J.L.D. (2008). Optimization of the freezing process of red shrimp (Pleoticus muelleri) previously treated with phosphates. International Journal of Refrigerator 31: 1134-1144.

Haard N. (2002). The role of enzymes in determining seafood color and texture. In: Bremner A H, editor. Safety and quality issues in food processing. Boca Raton Boston New York Washington, DC: Wood Head Publishing Limited. 221-253.

Huss H.H. (1993). Assurance of seafood Quality. Rome: FAO Fisheries Technical Paper, No.334. 
Khristoferzen G. (1969). Polyunsaturated fatty acid content of fat of some Atlantic and Indian ocean fish. Voprosy Pitaniya 28: 86-87.

Liu SH, Li DT, Zhi Hong P, Hua Zhang C, Wu JH, Long Gao J, and Zhang L. (2009). Cholesterol, lipid content, and fatty acid composition of different tissues of farmed cobia (Rachycentron canadum) from China. Journal of the American Oil Chemists Society 86: 1155-1161. DOI:10.1007/s11746-009-1458-4.

Madrid A, Madrid J, and Madrid R. (1994). Tecnología del pescado y productos derivados. A. Madrid Vicente, Ediciones y Mundi-Prensa Libros, S. A., Madrid (Spain), 45-103.

Medina I, Gallardo J, and Aubourg, S.P. (2009). Quality preservation in chilled and frozen fish products by employment of slurry ice and natural antioxidants. International Journal of Food Science and Technology 44:14671479. DOI:10.1111/j.1365-2621.2009.02016.x.

Nazemroaya S, Sahari MA, and Rezaei M. (2009). Effect of frozen storage on fatty acid composition and changes in lipid content of Scomberomorus commersoni and Carcharhinus dussumieri. Journal of Applied Ichthyology 25: 9195. DOI: 10.1111/J.1439-0426.2008.01176.X.

Ozogol F, Polat A, and Ozogul Y. (2004). The effect of modified atmosphere packaging and vacuum packaging on chemical, sensory and microbiological change of sardines (Sardina pilchardus). Food Chemistry 85: 49-57. DOI: 10.1016/j.foodchem.2003.05.006.

Perez-Alonso F, Aubourg SP, Rodriguez O, and Velazques J. (2004). Shelf life extension of Atlantic pomfret (Brama brama ) fillets by packaging under vacuum-skin system. Food Research and Technology 218:313-317. DOI:10.1007/s00217-003-0831-z.

Pettersen M.K, Mielnik M.B, Eie T, Skrede G, and Nilsson A. (2004). Lipid Oxidation in Frozen, Mechanically Deboned Turkey meat as affected by packaging parameters and storage conditions Poultry Science 83(7):1240-8.

Rostamzad H, Shabanpour B, Kashaninejad M. and Shabani A, (2010). Inhibitory impacts of natural antioxidants (ascorbic and citric acid) and vacuum packaging on lipid oxidation in frozen Persian sturgeon fillets. Iranian Journal of Fisheries Science 92: 279-292.

Saldanha T, and Bragagnolo N. (2008). Relation between types of packaging, frozen storage and grilling on cholesterol and fatty acids oxidation in Atlantic hake fillets (Merluccius hubbsi). Food Chemistry 106: 619-627.

Sawant S.S, Sawant D.V, Shrangdher S.T, Koli J.M., Shrangdher M.T, and Metar S.Y. (2012). Effect of vacuum packaging on shelf life of frozen shrimp. CIBTech Journal of Biotechnology 1(1): 27-35.

Selami S, and Sadoki S, (2008). The effect of natural antioxidant (Thymus vulgaris Linnaeus) on flesh quality of tuna (Thunnus thynnus Linnaeus) during chilled storage. Pan-American Journal of Aquatic Science 3: 36-45.

Serdaroglu M, and Felekoglu E. (2005). Effects of using rosemary extract andonion juice on oxidative stability of sardine (Sardina pilchardus) mince. Journal of Food Quality 28: 109-120. DOI:10.1111/j.1745-4557.2005.00016.x.

Shirai N, Higuchi T, and Suzuki H. (2006). Analysis of lipid classes and the fatty acid composition of the salted fish roe food products, Ikura, Tarako, Tobiko and Kazunoko. Journal of Food Chemistry 94:61-67.

Taheri S, Motallebi A.A, Fazlara A, Aftabsavar Y, and Aubourg SP. (2012). Effect of previous ascorbic acid treatment on the fatty acid profile of cobia ( Rachycentron canadum) fillets during frozen storage. Grasas $Y$ Aceites 63, 1: 70-78. DOI:10.3989/gya.070711. 